\title{
TERRITORIO Y VIOLENCIA EN LAS COMUNIDADES MAPUCHES DE LA PROVINCIA DE ARAUCO (SIGLO XX). UNA RECONSTRUCCIÓN DESDE LA HISTORIA ORAL *
}

\author{
TERRITORY AND VIOLENCE IN THE MAPUCHE COMMUNITIES \\ OF THE PROVINCE OF ARAUCO (2O TH CENTURY). \\ A RECONSTRUCTION FROM ORAL HISTORY
}

\author{
Alejandro Clavería**, Jorge Iván Vergara*** y Hans Gundermann ${ }^{* * * *}$
}

\begin{abstract}
Desde el testimonio oral entregado por dirigentes mapuches en las luchas de recuperación territorial en Arauco, durante el siglo XX, se presenta una reconstrucción interpretativa de estos procesos, relevando la importancia de organización colectiva. La temprana vinculación de líderes y comunidades mapuches de la provincia con el mundo de las cercanas explotaciones carboníferas y su activismo sindical, otorgó al movimiento mapuche de la costa de Arauco un matiz específico que lo distinguió y lo convirtió en precursores de las luchas de recuperación territorial de su pueblo.
\end{abstract}

Palabras claves: Pueblo mapuche, siglo XX, provincia de Arauco.

From Mapuche leaders' oral testimony during the struggle for territorial recuperation in the Arauco region during the 20th century, we present an interpretative reconstruction of these processes, revealing the importance of collective organisation. The early relationship between regional Mapuche leaders and communities and the world of the nearby coal mines and their trade union activism provided the coastal Mapuche movement in Arauco a specific nuance that distinguished them and made them a precursor to their people's struggles for territorial recuperation.

Key words: Mapuche people, XXth Century, Arauco Province.

\section{Introducción}

El objetivo de este trabajo es describir, desde la historia oral, cómo las comunidades y organizaciones mapuches de la Provincia de Arauco (Región del Bío-Bío) buscaron revertir el masivo despojo territorial sufrido con la ocupación definitiva de la Araucanía, a fines del siglo XIX, y el proceso de radicación (1883-1929). Este esfuerzo debe ser comprendido como parte de las luchas de restitución territorial del conjunto del pueblo mapuche, tanto en La Araucanía como en Valdivia, Osorno y Chiloé, pero tuvo aquí en Arauco un sello particular: el temprano influjo ejercido por el sindicalismo minero irradiado desde las cercanas explotaciones carboníferas de la parte septentrional de la Provincia, proceso en el que militantes y dirigentes de los partidos políticos de izquierda jugaron un papel central.

Entre dichos cuadros partidarios se destacaron hombres mapuches que trabajaron en las faenas del carbón, o bien mantuvieron prolongado contacto con activistas sindicales, y que luego, a partir de la segunda mitad del siglo XX, se involucraron activamente en las luchas de restitución de tierras. A través de entrevistas a ex dirigentes y ex militantes comprometidos en este proceso hasta fines de la década de 1980, buscaremos reconstruir el cuadro de la lucha por la recuperación territorial desde la memoria de algunos de sus protagonistas. El enfoque metodológico que guía este trabajo es la historia oral, estructurada con base en trece testimonios orales recogidos en entrevistas realizadas principalmente entre 2015 y 2016, en diferentes localidades de la Provincia de Arauco ${ }^{1}$. A modo complementario, se proporciona información recopilada en archivos públicos, presentada en estudios anteriores y también información de prensa. Sobre todo, nos interesa recoger la perspectiva mapuche acerca de estos complejos procesos, la forma en que los interpretan y valoran.

\footnotetext{
* Este trabajo ha sido elaborado en el marco del proyecto Fondecyt 1141077.

** Universidad de Concepción. Concepción, Chile. Correo electrónico: alclaveria@udec.cl

*** Universidad de Concepción. Concepción, Chile. Correo electrónico: jorgeivergara@udec.cl

****Universidad Católica del Norte. San Pedro de Atacama, Chile. Correo electrónico: gundermann.hans@ gmail.com
} 
Se busca describir sintéticamente un proceso de pérdida/reapropiación territorial que transcurrió a lo largo de varias décadas, que concierne además a un espacio relativamente amplio (una provincia), diferenciándose de valiosos trabajos previos que, ocupando también testimonios orales, se abocan más bien a un dirigente, una comunidad o un conjunto de comunidades ${ }^{2}$.

Asimismo, y como sabemos, la memoria es siempre selectiva y supone, por tanto, el olvido de ciertos aspectos en favor de otros (Todorov 2015: 18). No es la precisión en los nombres de personas o las fechas lo que se preserva, mientras los lugares de origen y desplazamientos se han conservado muy bien en el recuerdo de las comunidades. Como señala Todorov, memoria e historia son diferentes, pero también pueden complementarse: "en vez de oponerse a la memoria, la historia permite enriquecer su sentido haciéndola compartible por una comunidad más amplia" (Todorov 2013: 25-27).

Por otro lado, la indagación histórica propuesta nos permite esbozar -aunque sin profundizar- lo que un reconocido especialista, Alessandro Portelli, ha denominado acertadamente: "la batalla por el significado y la memoria" (Portelli 2004: 23). Una lucha por las significaciones que ha tenido lugar desde el inicio mismo de los procesos narrados y que, en nuestro caso, toma partido por la perspectiva de quienes han sido generalmente ignorados o despreciados por la historia (en el doble sentido de la expresión: como historiografía y como conjunto de procesos reales). Y que comprende reconocer la diferencia "entre lo que consideramos un hecho y lo que ocurre en la memoria, incluyendo acontecimientos imaginarios y falsos recuerdos" (Portelli 2002: 163). De ahí la necesidad de confrontar los testimonios orales entre sí y enriquecerlos con fuentes de archivo y de prensa, además de estudios ya realizados (Hoffman, 1987).

\section{De la violencia de la usurpación a la radicación}

La pérdida territorial sufrida por los mapuche de Arauco a partir de la segunda mitad del siglo XIX se caracterizó por la ausencia de Estado como principal colonizador en beneficio de la penetración de la propiedad privada, que consolidó su avance en el acceso a la tierra, principalmente, a través de los mecanismos de arriendo, donaciones y "venta de acciones y derechos" (Molina s/f.; Foerster 2008 y 2018: 208-216). Tales mecanismos permitían sortear las restricciones a la enajenación de tierras indígenas impuestas por el decreto de 14 de marzo de 1853 y por la ley de radicación del 4 de diciembre de 1866. Posteriormente, se permitió la libre enajenación de tierras indígenas en la Provincia de Arauco desde el río Paicaví y el lago Lanalhue hacia el norte (ley del 4 de agosto de 1874) y, luego, desde la ribera septentrional del río Tirúa (ley del 13 de octubre de 1875); es decir la exención abarcaba todo el departamento de Lebu y la parte norte del de Cañete (al sur de Tirúa los terrenos fueron declarados fiscales y las restricciones de venta se mantuvieron). Con estas liberaciones, y la subsiguiente legalización e inscripción de los contratos de compra de tierras, comenzó la constitución formal de la propiedad particular en toda esa extensa área que, a la sazón, ya estaba extensivamente colonizada. Esto supuso la regularización de numerosos abusos anteriores de los propietarios privados contra los mapuches:

"Los contratos a partir de ese momento habían logrado establecer el traspaso de los terrenos arrendados a los mapuches en propiedad a los colonos chilenos que los usufructuaban....La libre enajenación de tierras indígenas decretadas para Arauco generaba una serie de irregularidades, abusos y fraude contra el indígena, al legalizarse muchos contratos de arriendo, hipotecas, compromisos de venta y otros diferentes, como contratos de ventas, lo cual constituía una forma velada de usurpación de tierras que conducía al arrinconamiento del mapuche en el territorio comprendido entre Lebu y Tirúa” (Molina s/f.: 107).

En la memoria mapuche se ha conservado el recuerdo de este proceso. Como señala Lorenzo Neculqueo, actual lonco del sector de Tranaquepe, en Tirú:

Lorenzo: ¿Cómo entraron estos caballeros aquí? No quitando, llegaron como arrendando, "¿Por qué no me arrienda un poquito de tierra, aquí, para criar un animalito? Y, yo le doy alimento y le voy 
pagando". Y convinieron, según el cacique, porque no había hartas familias. Los mayores caciques, en cada comunidad, no habían más de tres, cuatro, más no habían, mandaban en todas las partes [...] Entonces le arrendaban ellos: "Ya pues, pero el compromiso, tenemos que hacer un papel". "Ya, pues". "Y queremos para esto nosotros, para tener una vaquita, dos, y nosotros los socorremos a ustedes", le da triguito, le daría moneditas, también, y le socorría así, pancito, de repente, quesillo, quesito [...] "Ya pues, compadre, aquí hagamos, yo quiero hacer un cerco, lo encierro". "Ya, listo no más". "Pero tiene que firmarme la autorización". "Sí, listo". Le ponían el dedo, porque ni un mapuche sabía leer, le ponían el dedo, ahí: "Aquí, mira, vamos derechito al cerro, a ese cuadrado, acá". Pasó un año más: "Véndeme otro pedacito más, compadre. Ustedes mismos van a cuidar aquí, pasémoslo bien, y yo traigo más animales". "Ya, pues". Y así los otros también estiraban, cerro a cerro, plantaban una varilla acá y allá, listo. Y así se fue quedando con toda la tierra al final.

Pregunta: O sea, eran arriendos y los hacían pasar por venta.

Lorenzo: Por venta, claro. Ahí tenía derecho. Yo, eso le escuché a unos ancianos, una anciana así [...] Y así comenzaron a entrar estos caballeros ${ }^{3}$.

Como señala el lonko Neculqueo, los procedimientos habituales para la adquisición de tierras por parte de colonos o chilenos se realizaban con base en engaño: la realización de un aparente arriendo que, gracias al desconocimiento del español por parte de la gente mapuche, era en realidad una compraventa de terreno, lo que les permitía hacerse dueño de toda la tierra. A consecuencias de este proceso de usurpación, se produjo una masiva retirada de las comunidades mapuches desde los terrenos despojados hacia aquellos espacios que se encontraban hasta entonces libres de la presión colonizadora, y que se constituyeron por tanto en zonas de refugio. Junto a los terrenos ubicados al sur de Tirúa, la alta cordillera de Contulmo fue uno de dichos espacios, también declarado fiscal, adonde llegaron numerosas familias a establecerse:

Juan....Es que, fue fuerte la cosa. Los que se fueron de..., la familia mía era de aquí del lado de la costa, el lado de Quelihue, entre Ponotro y Quelihue, ahí vivía mi abuelo. De ahí los corretearon ${ }^{4}$, se fueron allá al lago, se fueron a tirar al otro lado del lago, a Huallepén Bajo. En Huallepén empezaron a formarse las comunidades.

Pregunta: Ponotro, Quelihue, ¿eso es como de Cañete hacia la costa?

Juan: Sí. Ahí vivía mi abuelo, Ignacio Viluñir Huilipan, ese era mi abuelo. Ahí tenían tierra. Por ahí se pusieron los huincas.

Pregunta: ¿Se fue mucha gente?

Juan: Harta gente. En Huallepén, Tricauco, los Nanco, se formaron cuatro comunidades. Ahí se fueron repartiendo ellos, porque esas eran tierras fiscales.

Pregunta: Y así como los Viluñir que se fueron para allá, ¿Qué otro apellido, qué otra gente se fue para allá?, apellidos Nanco, me dijo Ud.

Juan: Ñanco, varios. Ahí se fueron los Antimanes, los, estos otros, los Antimanes, los Reinao, ¿cuánto?, una familia larga que hay en Huallepén, los Reinao, yo los conozco a todos. Se fue harta gente . $^{5}$

Como dijimos, en las comunidades mapuches de Arauco está muy presente el recuerdo del lugar desde donde fueron echados y hacia donde llegaron. Se establece una conexión entre el lugar perdido y el lugar de refugio, las señas de lugar emergen prontas y nítidas para ir relacionando un recuerdo con un territorio perdido pero, a la vez, potencialmente recuperable. La realización de esa potencia se evidencia nítidamente en el siguiente testimonio, donde Santos Huenullán ${ }^{6}$ describe las tomas de terreno realizadas por cuatro comunidades vecinas en la década de 1960. Con ellas se buscaba recuperar las tierras de las que habían sido despojadas un siglo antes. Dichas recuperaciones se justifican a partir del momento de la "pérdida original":

La realización de esa potencia a partir de la pérdida es lo que presenta el testimonio de Santos 
Huenullán ${ }^{7}$ al referirse a las tomas de terreno que, ya muy avanzado el siglo XX, realizaron cuatro comunidades vecinas para recuperar las tierras de las que fueron despojadas alrededor de un siglo antes. Destaquemos cómo esas recuperaciones posteriores se justifican a partir del momento de la pérdida original:

... [Decidimos] unirnos y pedir que las tierras volvieran a nosotros, porque sabíamos nosotros, porque siempre contaban, al abuelito de ellos que le quemaron sus casitas en Puañil, a este lado. Y de ahí les quemaron sus casas a ellos, fueron a Cañete, cuando volvieron, estaban prendiendo las casitas y todas las cosas, los tenían en una reducción chica, donde queda al lado de una quebradita que hay, amontonados. Y ahí quedaron ellos y qué le iban a hacer, porque carabineros, los camperos, todo, los plantaron y ahí quedaron. Entonces sabíamos que esa tierra era de nosotros, del abuelo, de los antepasados, porque eran dueños de aquí. El dueño efectivo era Epullán, Francisco Epullán se llamaba. Era lonco, porque lonco era el que mandaba todo el terreno [...] Ellos llegaban, llevaban su gente y los plantaban nomás, ahí no avisan na, llegan. Nos reducían nomás y uno, como no había autoridad, así que ahí se quedaban ellos, y sin armas, sin nada, entonces ahí quedaron nomás [....] Y al refugiarse el lonco, los otros tienen que [seguirlo]. De esa manera nos desalojaron de esta tierra, le quemaron ahí, lo arrinconaron, adonde me crié yo, la reducción, ahí quedamos nosotros [...] Después siguieron juiciando ${ }^{8}$, pero no pasó nada ${ }^{9}$.

Como señalamos, hubo también comunidades que, frente a la desposesión de sus terrenos, en vez de desplazarse hacia otras áreas, permanecieron en la estrecha superficie a la que se vieron reducidos por los usurpadores. No fue sino a partir de 1898 que algunas de estas pequeñas zonas de refugio fueron reconocidas por el Estado, cuando en Arauco comenzó a operar la Comisión Radicadora de Indígenas (1884-1929), en cumplimiento de lo dispuesto por la Ley de Radicación de 1866, otorgando Títulos de Merced sobre el reducido territorio que las comunidades efectivamente ocupaban. La constitución de la propiedad indígena reduccional en Arauco significó el otorgamiento de 77 títulos de merced, sobre un total de 9.700 , 59 hás., con una población radicada de 2.477 personas, lo que da una tasa de 3, 92 hectáreas por persona, la más baja entre todas las provincias en que operó la Comisión (González, 1986).

\section{La influencia del sindicalismo minero en la lucha por la recuperación territorial}

Frente a la violencia que encerró el proceso de expoliación recién señalado, la recuperación de las tierras se constituyó en la principal demanda de los mapuches de Arauco. No existe una investigación en profundidad sobre las formas en que esta demanda se gestionó desde las comunidades de la Provincia durante la radicación y hasta bien entrado el siglo XX. La información disponible habla de gestiones intermitentes ante la autoridad encabezadas por los caciques y en la que actuaban conjuntamente varias comunidades. Por otra parte, se constata tanto la inexistencia de actividad en Arauco de las macro organizaciones mapuches de la primera mitad del siglo XX, la Sociedad Caupolicán y la Federación Araucana, como la ausencia de una organización que articulara y representara consistentemente su demanda por tierra (Foerster 2018: 257-269). La frase recién citada de Santos Huenullán: "Después siguieron juiciando, pero no pasó nada", quizás da cuenta de ello.

Sin embargo, la demanda por la restitución de tierras en Arauco encontró otro cauce por el cual desarrollarse. En las tres primeras décadas del siglo pasado, se dejó sentir sobre el mundo mapuche provincial la influencia ejercida por los movimientos y partidos de raigambre obrera, fundamentalmente los Partidos Comunista y Socialista. Ello le dio un matiz de clase al accionar $\mathrm{y}$ al discurso de la dirigencia provincial mapuche. El contexto de esta relación está dado por la cercanía geográfica de las comunidades y reducciones mapuches de la zona con los importantes yacimientos de explotación carbonífera situados más al en el norte (Lebu, Curanilahue, Arauco y Lota), en los que se desarrolló, desde muy temprano, un poderoso activismo sindical y partidario, inserto en el marco de las luchas obreras. En esos centros se estableció un contacto histórico entre el 
mundo sindical e importantes sectores del mundo mapuche, vehiculado principalmente a través de la inserción laboral de muchos mapuches en las faenas carboníferas.

Cuando contaba con 17 años, el dirigente Juan Neculqueo, del sector de Huentelolén en la comuna de Cañete, ingresó a trabajar a las minas y allí se afilió al partido comunista:

Juan:... Yo soy el único que quedó como familia, como el grupo familiar Neculqueo Catrileo y una hermana menor [...] Y, después cuando volví acá me puse a disposición de las organizaciones, ya fui werkén, como emisario para llevar esto acá y allá, empecé ya. Pero mucho antes que fuera al servicio militar yo era, había pasado yo en Lota, trabajé en la mina carbonífera, tenía 17 años [en 1952]. Trabajaba en la mina carbonífera, en el pique grande, se llamaba Arturo el pique grande, Arturo Cousiño [...] En Lota, ya participaba en las juventudes comunistas.

Pregunta: Porque los sindicatos eran muy fuertes, todo eso.

Juan: Claro, habíamos como 15.000 obreros todavía en ese tiempo, era una de las organizaciones más fuertes que había en Chile ${ }^{10}$.

El ingreso al Partido Comunista a través de la conexión minera está presente también en los inicios de la trayectoria directiva del recordado lonco de la comunidad de Choque (ribereña del Lleu Lleu), Lorenzo Carilao. Su hijo Juan Carilao señala:

Juan: Fue, claro, digamos primero...uno de los primeros dirigentes del partido, fue él, claro, porque aquí no, nadie conocía eso. Y él no sé cómo entró a eso y le gustó y siguió en eso.

Pregunta: ¿Y usted sabe cómo, él trabajó en la mina?

Juan: No, no, él nunca trabajó en las minas. Él, no sé, dice que por su experiencia propia llegaba gente a la casa, llegaban así de repente, negociantes, vendiendo cosas, así, entonces ahí conversaban que eran ellos mineros y le decían que los mineros estaban igual como la conversa que les hacía él, que aquí los mapuches estaban arrinconados y sin embargo el fundo tenía tierra de sobra, tenía inquilinos y todos esos lo pasaban bien y la gente, los verdaderamente [mapuches] estaban reducidos en comunidades y obligadamente [tenían que ir a] trabajar al fundo, porque ahí estaba la comida, porque antes, los mapuches no sembraban, por las tierras que no daban ${ }^{11}$.

La primera expresión pública de esta confluencia se dio a partir de 1940, en el contexto de los gobiernos del Frente Popular. En ese momento el Partido Comunista contaba con una orgánica específica para acoger y articular la demanda de las comunidades mapuches: el Frente Único Araucano (FUA), nacido un año antes en Temuco (Foerster y Montecino, 1988: 158). La rama provincial del FUA en Arauco tuvo su base principal en la reducción de Pangue (actual comuna de Los Álamos), hasta donde llegaron dirigentes de la zona carbonífera a incentivar el establecimiento de esta organización (Foerster 2018: 259-269 y 290-291). Debe añadirse que durante esa década el partido comunista llegó a ser la principal fuerza política provincial. En las elecciones de regidores de abril de 1947, el PC eligió 14 regidores en la provincia, entre los cuales estaba el presidente del FUA provincial, Juan Aniñir Cheuquelen (de Pangue). El FUA provincial contó además, durante esa década, con otros dos regidores en las municipalidades de Cañete y Los Álamos. La promulgación de la Ley de Defensa de la Democracia en 1948, que proscribió al Partido Comunista, significó el fin abrupto del FUA y el apresamiento de algunos de sus dirigentes, como su secretario general Pedro Yevilao Catrilelbun (también de Pangue), quien estuvo relegado en la Isla Quiriquina (Foerster 2018: 269) ${ }^{12}$. Los dirigentes más cercanos a la izquierda conformaron en 1953 la Asociación Nacional de Indígenas de Chile y después en la Federación Campesina e Indígena, ligada al PC (Foerster y Montecino, 1988: 170 y Foerster 2018: 294).

No obstante la proscripción, el partido comunista prosiguió con sus actividades en la zona. El esfuerzo del PC por formar a sus cuadros y darles seguimiento tuvo un especial efecto en sus militantes mapuches, muchos de los cuales 
contaban con una escolarización muy baja, o carecían totalmente de ella. El adoctrinamiento lo proporcionaba el partido en distintas instancias de formación:

Juan Carilao: Pero siempre en cualquier discurso él [su padre] decía: "El Partido Comunista me educó y por eso aprendí y por eso sé adónde estoy, y sé que [los comunistas] no son igual que estos traidores que le venden la pomada a uno y después lo traicionan con el mismo puñal".

Pregunta: ¿Su padre empezó a leer con el partido?

Juan Carilao: Sí

Pregunta: ¿O en la escuela?

Juan Carilao: No, después se educó así [...] Si también lo llevaron, tuvo unos cursos decía, en Lota, ahí, no sé dónde [...] Y después ya fue, digamos, un profesor más acá en la zona.

Posteriormente, la influencia sindical y partidaria en el movimiento mapuche provincial se expresó en el activismo protagónico que un amplio abanico de dirigentes de raigambre carbonífera (mapuches y no mapuches) tuvo en las luchas por la recuperación y ampliación de las tierras por diversas comunidades mapuches, luchas que tuvieron su cúspide durante la reforma agraria emprendida por el Estado chileno entre 1960 y $1973^{13}$. Aquí jugaron un papel especial los esfuerzos emprendidos por formar sindicatos campesinos en las comunidades mapuches.

Jovelino Liencura fue uno de los más destacados activistas provinciales en la promoción de la ley de sindicalización campesina promulgada en 1967. Nacido en Quiapo, al norte de Lebu, muy joven ingresó a trabajar a las minas de carbón de Lebu donde se hizo dirigente sindical y también comunista. En 1966, por orden partidaria tuvo que reorientar su activismo:

...El año 66 yo renuncié [a la dirigencia sindical minera] porque a mí me sacó la Central Única Nacional de Trabajadores cuando se inicia, o sea cuando sale la ley de sindicalización campesina. Y les expliqué a los trabajadores por qué, que aquí existían las organizaciones que solucionaban los problemas de los mineros, y que había aprendido mucho de ellos, y la realidad que aprendí mucho de ellos, y [que] yo me iba a servirle a gente que necesitaba personas quienes también los instruyeran en cómo defender sus intereses, en las reducciones. Y bueno, eso fue lo que se planteó de acuerdo a los dirigentes a nivel nacional $[\ldots]$ y en ese entonces el PC fue el que me llevó a mí, el PC me financiaba a mí ${ }^{14}$.

Su elección por parte del partido obedeció a su condición de mapuche: "Una, que me trajeron para acá porque existían muchas reducciones indígenas por estos lados de Cañete, y el problema indígena, cuando llegaban los blancos, los huincas, no los pescaban por haber sido traicioneros, qué sé yo, en la cuestión de la llegada, entonces yo calcé ahí. Me metía dentro de las reducciones, no tuve mayores problemas en ninguna parte $[\ldots .$.$] yo$ cuando llegaba a las reducciones me identificaba como indígena" 15 .

El afán por "instruir" y "organizar" a las comunidades mapuches en la defensa de sus intereses se enfocó prontamente en la lucha por la recuperación de las tierras usurpadas:

Y empecé, de aquí le pegaba un buen poco al sistema de cómo anteriormente tenían las escrituras, por la posesión efectiva de los mapuches, las reducciones, y donde existían las ventas, vendían una hectárea y le tenían tomado 20,50, 100 hectáreas a los mapuches. Entonces empecé a ver todo eso, y empezamos a pelear las tierras, claro, porque si se hallaban en dos hectáreas y les tenían tomadas 100 hectáreas a las reducciones, entonces. Y ahí empezaron las tomas de tierras también. Formando sindicatos, tomas de tierra, pidiendo la devolución de las tierras a los mapuches. $\mathrm{Y}$ en eso me las gané ${ }^{16}$.

Había, sin embargo, un aspecto que entorpecía la consecución de este objetivo: la dificultad para conformar una representación colectiva que agrupara a un conjunto de comunidades en la demanda por la ampliación y restitución de tierras:

Jovelino: Ellos, nunca se les pudo sacar eso, ellos su directiva, todo, pero cuando 
[había que unirse] salían en bandada, por ejemplo reducción tanto, Ranquilhue Chico, Ranquilhue Grande, Choque, y cada una salían sus dirigentes, pero salían dos de cada parte.

Pregunta: O sea, ustedes [PC] tenían que entenderse con cada reducción específicamente.

Jovelino: Eso es. Cada uno se manejaban ellos. Y nunca se les pudo sacar, yo creo que ahora están en las mismas. Y ellos confían en los dirigentes que tienen en sus reducciones, en su sector, y desconfían hasta de cualquier otro de al lado que sea dirigente mapuche. Es muy desconfiado el mapuche, nuestra raza es desconfiada [...] [En cambio,] en Huentelolén fue fácil, no fue tan difícil. Costó menos ahí, a pesar de que había más analfabetismo, pero costó menos ahí.

Si bien la división interna constituye un rasgo característico de las comunidades mapuches rurales, de acuerdo al testimonio citado este habría tenido una expresión más acentuada en el caso de la Provincia de Arauco.

\section{El impacto de la reforma agraria en las comunidades de la Provincia de Arauco}

La afirmación de Liencura acerca de la debilidad de la representación colectiva debe ser relativizada, especialmente para el momento histórico que se afrontaba. La implementación de las políticas de reforma agraria durante ese período tuvo en las comunidades mapuches de la provincia de Arauco un impacto y significación especial ${ }^{17}$. Ya desde inicios de los sesenta, y durante todo el transcurrir de esa década y principios de la siguiente, se manifiesta, si bien de manera episódica, una capacidad organizativa supracomunitaria capaz de gestionar de manera exitosa la demanda por la restitución y ampliación de tierras. En su surgimiento jugó un papel muy importante la vinculación, ya para entonces suficientemente madura, entre determinados sectores del mundo mapuche y las organizaciones sindicales y partidarias que operaban en las cercanas explotaciones carboníferas.

A lo largo de esos años, las diversas agrupaciones mapuches de Arauco, dirigidas en su gran mayoría por militantes o simpatizantes del Partido Comunista, y en menor medida del Socialista, fueron presionando a las autoridades locales y nacionales para conseguir la ampliación o restitución de las tierras usurpadas. La estrategia preferente de presión fueron las tomas de terrenos. Dirigidos, apoyados y/o acompañados por un plantel de activistas, líderes sindicales y campesinos así como por diputados, senadores y regidores de los partidos mencionados, los mapuches fueron ocupando fundos en poder de grandes terratenientes locales. Algunas de las tomas generaron un gran impacto provincial e, incluso, nacional.

Los resultados de este proceso en términos de cantidad de tierras recuperadas pueden calificarse de exitosos. En el decenio que corre entre 1962 y 1972 (es decir, considerando las tres etapas de la reforma agraria), el Estado chileno entregó en toda la provincia un total de 18.699 hectáreas de terreno a 298 parceleros mapuches. Para dimensionar esta cifra, debe recordarse que, en la misma provincia, el Estado entregó, vía títulos de merced, un total de 9.700 hectáreas. Es decir, al final del proceso de reforma agraria los mapuches de Arauco vieron duplicadas sus tierras en relación a las que se les reconoció en el proceso de radicación (Foerster 2018: 320).

A medida que aumentaban las ocupaciones de tierras, estas fueron desplazándose desde el norte al sur del territorio. No fue casualidad que esa cadena se iniciara en la zona aledaña a la reducción de Pangue, en la comuna de Los Álamos. Fue allí donde el FUA sembró su simiente en los años cuarenta y allí vivían todavía algunos de los antiguos dirigentes comunistas, como Pedro Yevilao Catrilelbun, expresándose nuevamente la incidencia de dicho Partido en el desenvolvimiento de estos acontecimientos. La toma de la Isla Pangal (Departamento de Lebu), un terreno en poder de Carlos Larroulet, iniciada el 25 de enero de 1962 y que se prolongó cerca de dos meses, involucró a cinco comunidades aledañas, y se constituyó en "el paradigma de la lucha por la tierra" (Foerster 2018: 287).

Alfredo Aniñir, de la reducción de Pangue, entonces de catorce años, estuvo en la toma acompañando a su padre:

...Estábamos más cerca de la isla Pangal, estábamos más cerca. Entonces, la gente 
ahí iban a echar sus caballos, echar sus bueyes. Lo hacían pastar un rato, de ahí los traían porque ya, escaseaba el pasto [...] entonces iban escondidos, y estos señores cuando los veían ahí, tocaba que los pillaban, ellos los agarraban, los tomaban detenidos, los detenían y los llevaban para Yeneco [donde estaba la casa patronal de Larroulet] y tenían que pagarle el perjuicio del talaje. Esa orden tenían ellos, por lo que ellos decían [...] Esto [la toma] ellos ya lo tenían planificado, pero estaban unidos, aliados con 5 comunidades, Pangue, Trauco, Pitracuicui, Ranquilco y Rucaraqui, esos, las 5 reducciones. Si todos en la comunidad de Pangue, por lo menos hay, iban algo como 10 personas, y en Trauco iban otras 2 o 3 personas, así en Pitracuicui, iban 4, Ranquilco iban como 5 personas, una cosa así. Y Rucaraqui iban otros 5 más. Así que tanto, tanto, se juntaron todos, pero la lucha fue de las 5 comunidades. Donde ellos enfrentaron esta lucha del Pangal ${ }^{18}$.

Al cuarto día, y después de resistir un violento intento de desalojo por parte de carabineros, los ocupantes recibieron la nutrida visita de apoyo de representantes políticos, a lo que se sumó en las semanas siguientes la ayuda brindada por integrantes de base y dirigentes de los sindicatos mineros:

....Y otra gente, otras pocas personas salieron [de la toma], se retiraron ahí, porque venían a encontrar otros funcionarios que iban a llegar. Cuál eran los funcionarios, incluso después llegaron. Fue un diputado, un senador, todos eran del Partido Comunista. Fue un periodista, llegó un presidente de una federación agrícola, fue don Pascual Melita [regidor por Los Álamos], que ese era uno de los coordinadores, llegó el señor diputado, don Santos Leoncio Medel ${ }^{19}$, todavía me acuerdo del nombre, y el senador, don Luis Corvalán ${ }^{20}$. Esas son las personas importantes que llegaron ahí [...] (Alfredo Aniñir).
Asimismo, el testimonio de Alfredo Aniñir destaca la enorme solidaridad recibida por quienes realizaron la toma:

Entonces ahí llegaron, fíjese, y nosotros, una alegría grande, como niños, alegría, porque vimos tanta gente. Detrás de esos venían más personas, total, venía un grupo, fíjese, pero hartos. Yo dije: “¿De a dónde salieron tanta gente?", si habíamos poquitos, antes de eso habíamos pocos [...] Pero, después, todas las semanas, los fines de semana, los días domingos llegaron, ahí llegaba cualquier gente de la zona minera, a visitar llegaban sus 20,15, 30 personas. Todos nos venían a visitar los días domingos. Venían de Pilpilco, después venían de Lebu, venían de Plegarias, venía otro grupo de Coronel, de Lota, toda esas partes, venían a visitar. Todos llevaban cajas y cajas, traían cosas, víveres. Gracias a ellos, gracias a la sindicalización, de todos los aportes de los obreros, de todos, de todo lo que cooperaron ahí se ganó la lucha Pangal. Y si no hubiera sido por eso, a lo mejor todos los dirigentes mayores se habrían venido, porque ya no había pan, ya no había alimento, todo eso. Y a voz de eso, como ya hubieron comentarios de que ahí la gente recibió mucha ayuda, personas que fueron opositores en ese momento, en esos días fueron opositor, y también [se sumaron luego] por recibir la ayuda (Alfredo Aniñir).

A fines de marzo de 1962, los ocupantes lograron la recuperación de la Isla Pangal. A partir de ese momento y hasta su subdivisión en 1980, las cinco comunidades ocuparon colectivamente el terreno como empastada para sus animales. Fue la primera gran recuperación de terrenos para los mapuches de Arauco en todo el siglo XX. El impacto de este hecho fue enorme en toda la provincia, y más allá de ella ${ }^{21}$. Para las comunidades mapuches se convirtió en un hito:

...A fin de marzo se ganó la lucha del Pangal. Entonces, en ese año, en ese año fíjese, aquí no se mejoró solamente los campesinos, los de isla Pangal, 
porque esta lucha, esto fue publicado a nivel nacional, fue la primera lucha de la Provincia de Arauco que se dio el año 1962, una recuperación de tierra, que recuperaron los mapuches. Y este comentario fue, llegó hasta internacional. Comentarios, diarios, qué sé yo [...] En esos años, que se puede decir que se abrió la puerta y Chile, fíjese, abrió la puerta, se mejoró, no solamente nosotros, sino [también] los campesinos, la zona minera, empleados públicos, todo, fíjese fue un mejoramiento, porque se les dio, como que se le torció la mano a la derecha, hubo mejor educación [...] De ahí ya empezó a continuar, porque después ya, otro dijo lo mismo, ya, como se ganó la Isla Pangal, así que, después empezaron a expropiar fundos y así fueron. Fue una historia tremenda esta, pero fue nada más que por la lucha de la Isla Pangal, ese fue el punto de referencia (Alfredo Aniñir).

La recuperación de El Pangal gatilló una serie de nuevas ocupaciones de terrenos protagonizadas por comuneros mapuches que buscaban presionar a las autoridades para que procediera a expropiar fundos ${ }^{22}$. Una consecuencia de esto fue la reactivación de la vida organizativa al interior de las comunidades mapuches. Silvia Naín, de Pangue, cuyo padre participó en la toma del Pangal, relata:

....Entonces, después se empezaron a afirmarse de los dirigentes y ahí se nombraron dirigentes, se nombró un dirigente por cada territorio. Así que había como seis dirigentes. $\mathrm{Y}$ estos dirigentes fueron gestionando y eso, lo avisaban: "Ya, tal día nos vamos a tomar el fundo tal, así que el que no tiene tierra tiene que ir para allá". Y todo escrito, con toda la cosa. Si eran casados, si no eran casados, cuántos hijos, de qué vivían. Hacen un diagnóstico bien acabado, la misma gente de la comunidad $^{23}$.

Junto con ello, se reactivó la coordinación y la cooperación entre las diversas comunidades de Arauco. Durante la misma toma del Pangal, los ocupantes no sólo obtuvieron el apoyo sindical y partidario, sino que también recibieron la visita de representantes de comunidades mapuches, sobre todo del sur de la Provincia:

Santos Huenullán: Claro, yo ya estuve también en El Pangal. Estuve conversando con los dirigentes antiguos. Yo era joven, [tenía] 17 años, los loncos me nombraron como delegado, como yo sabía leer un poquitito, me tiraron como delegado. Y estuve allá en la Isla del Pangal, como dos fuimos. Ahí tenían ruquitas todos, 40 ruquitas, así. Allí, estaban ellos, los peñis. Fue un Nguillatún, ahí llegamos, estaban rogando a mi Dios, como para que les saliera bien esto ${ }^{24}$.

Pregunta: ¿Y qué fue lo que Ud., más aprendió cuando estuvo en El Pangal? ¿Qué fue lo que más le impresionó?

Santos: Mire, cuando fui para allá, lo que más me interesó fue la unión que tenían ellos entre jóvenes, hermanos, adultos, todos unidos con su casita y hacían reunión y todos eran de una, o sea, estaban de acuerdo todos, luchar y reconquistar su terrenito. Entonces, eso fue lo que me gustó, la unidad, el trabajo de unidad con sacrificio, $[\ldots]$ Y ahí empecé a trabajar [...] Entonces, después, los peñis de Pangue también vinieron, vinieron dos delegados [...] así ellos vinieron, entonces ya aprendieron la gente, también y ahí se empezó a trabajar aquí, unidos. Después, ya nos organizamos, ya nos unimos y ahí se empezó a luchar por este fundo, claro, para hacer algo, para aprender o para reconquistar nuestras tierras, porque esta tierra era nuestra, de nuestros antepasados. De esa manera, con luchas, uniéndonos todos los peñis, entonces, de a poco ya van, nos van devolviendo...

Como vemos, las vinculaciones entre las comunidades mapuches se intensificaron al ritmo de las tomas en diversas zonas de la Provincia. Como consecuencia inmediata de la restitución del Pangal a los mapuches, el fundo Pangue (de propiedad de la familia Eyheramendy), aledaño a la reducción del mismo nombre, fue el primero en expropiarse ${ }^{25}$. Allí se constituyó la Colonia Indígena Rosa Esther Rodríguez de Alessandri, beneficiando con parcelas a mapuches de las 
cinco comunidades que ocuparon el Pangal. Nos encontramos en la primera etapa de la reforma agraria, bajo la ley $\mathrm{N}^{\circ} 15.020$, promulgada por el Gobierno de Alessandri en 1962, donde la figura de la colonia indígena suponía la entrega de parcelas individuales a los asignatarios, en contraste con lo que ocurriría en los asentamientos, a partir del Gobierno de Frei Montalva, donde los asentados usufructuarían colectivamente, hasta la parcelación definitiva, el terreno entregado tras la expropiación.

Apenas un mes después de concluida la toma en el Pangal, y luego de que el delegado Santos Huenullán volviera a su reducción en el sector de Huape (al sur de Cañete), se produjo la toma del fundo, de propiedad de la familia Ormeño. Las comunidades reduccionales de Pocuno, Collico, Puañil Chico y Puañil Grande entraron a principios de mayo de 1962 y contaron, nuevamente, con el apoyo de parlamentarios del PC y de mapuches de otras comunidades:

Sí, Santos Leoncio Medel, yo lo conocía antes, él venía por acá, porque, antes de ser parlamentario, o sea, se ubicaba con las comunidades, conversaba con las comunidades para ayudarlos. Eran conscientes, o sea, tenían buenas ideas con el pueblo mapuche. Entonces uno agradece bastante que aquellos parlamentarios ayudaron bastante, [dando] orientación, todo eso. Siempre me recuerdo de Jorge Montes, era parlamentario ${ }^{26}$ que vino a apoyar. Estuvo en la toma, aquí en Huape, digamos, si alojaba junto con nosotros, dándole charla, claro y como hay que unirse, con buenas ideas, pero jamás nunca nos dijeron que hay que tomar las armas, no "hay que ir conscientemente, si cae alguno detenido, vayan ustedes [y] declaran "por esto, por esto y por esto"”. Y aparte nos ayudaron los peñi de Lautaro y de Choque, allá también del sur vinieron a apoyarnos [...] Todos esos me acuerdo que esos ayudaron bastante, los peñis de las comunidades, porque nosotros pedíamos ayuda a ellos y ellos llegaban o se ofertaban a ayudar, porque no teníamos plata para abogados, entonces, ahí nos fuimos uniéndonos con ellos y ayudaron bastante... (Santos Huenullán).
Gracias al impulso y la experiencia del Pangal, el proceso aquí fue mucho más fluido. Luego de una semana del fundo Huape en toma, se comenzó a negociar la expropiación en beneficio de las cuatro comunidades implicadas. Allí se constituyó la Colonia Indígena Federico Peña Cereceda, la que, junto a la de Pangue, fueron las únicas Colonias Indígenas implementadas en la Provincia de Arauco, terminando así la entrega de tierras a mapuches de esta zona por parte del Gobierno de Alessandri (Foerster 2018: 302-310). No obstante, sobre la Corporación de Reforma Agraria (CORA) como sobre las autoridades provinciales se dejó sentir una presión creciente (tanto de mapuches como de inquilinos no mapuches) por acceder a la tierra que el Estado comenzaba a redistribuir. Muchas de estas autoridades tenían vinculaciones o pertenecían a los grupos terratenientes que veían disminuir sus propiedades. La amenaza de un desborde violento era esgrimida como el principal argumento para acelerar el proceso de parcelación, pero también era el justificativo para solicitar la adopción de medidas de fuerza. En un oficio confidencial enviado al ministro del interior por el gobernador de Cañete, Pedro Montory Athens, el 29 de septiembre de 1963, se señala:

Como es de su conocimiento a raíz de los serios incidentes de fines de 1961 y de 1962 en los Departamentos de Lebu y Cañete, por ocupaciones ilegales de fundos particulares por grupos mapuches y de manera de buscarle una solución a ese problema, la Corporación de la Reforma Agraria adquirió en estos lugares varios predios, con el objeto de hacer una parcelación a los indígenas, bajo control y supervisión técnica de funcionarios de esa Corporación....Sin embargo hemos tenido conocimiento que en las reducciones indígenas, especialmente en las partes cercanas a estos predios adquiridos, se han venido a instalar activistas comunistas venidos de Tomé, Curanilahue y otros puntos. Estos han estado adoctrinando a esta gente inculcándoles que el Gobierno ha tomado estas medidas gracias al plan de agitación que ellos han organizado y por lo tanto que para aspirar a obtener tierra 
es indispensable, como cuestión previa, incorporarse al Partido Comunista..... Existe el temor de que esto pueda derivar en una ocupación ilegal de algunas de estas propiedades u otras particulares, lo que tiene muy alarmados a muchos agricultores. Por coincidencia, en visitas que han efectuado entre los sectores indígenas de la zona, funcionarios de Asuntos Indígenas de Temuco, cuyo jefe era de raza mapuche, para hacer empadronamientos y otras encuestas, ellos lo han interpretado como un estímulo a sus pretensiones reivindicatorias, lo que en conjunto está despertando y alimentando una lucha racial que puede degenerar en graves hechos posteriores, lo que naturalmente está hábilmente estimulado por los agitadores comunistas, que abundan por nuestra cercanía a los grandes centros mineros del carbón....en los fundos Pangue y Sara de Lebu los inquilinos chilenos que se han resistido a plegarse a estos elementos disolventes, están amenazados por los mapuches de expulsarlos a la fuerza de esos lugares y no permitirles que vayan a permanecer como parceleros.....Estas circunstancias confirman la aspiración de mucho tiempo de la gente de esta zona, que es la de contar con un contingente militar en esta provincia, que es de las únicas del país que no cuenta con ella, y donde, por nuestro aislamiento y el peligro que significa vivir rodeado de minerales carboníferos y reducciones indígenas, se justifica más que en muchas otras partes la existencia de un cuerpo de esa naturaleza. Con su sola presencia cumpliría una misión de garantía y tranquilidad para toda nuestra gente que está viviendo en una inquietud constante ${ }^{27}$.

En representación de "nuestra gente", la autoridad provincial, atenazada entre los peligros que representaban los minerales de carbón y las reducciones indígenas, terminó solicitando el establecimiento de un contingente militar. Junto con apelar a la recurrida idea de la manipulación de los mapuches por activistas de izquierda, el gobernador alerta sobre una eventual "lucha racial" que pudiera desatarse entre "mapuches" y "chilenos" a propósito de la aplicación de las políticas de redistribución de tierras. El informe del gobernador realiza aquí una distinción implícita: sitúa la "lucha racial" entre mapuches y chilenos pobres, desposeídos de tierra, dejando fuera a los terratenientes, casi como una constatación del retroceso que estos últimos comenzaban a experimentar en el panorama provincial y nacional. Tanto en la Colonias Indígenas del período de Alessandri como en los asentamientos posteriores, junto a beneficiados mapuches, ingresaron y fueron asignatarios de parcelas ex inquilinos no mapuches de los fundos expropiados, quienes se vieron así favorecidos por la presión, vía tomas, que ejercieron los mapuches. Ahora, ¿esta "lucha" era real en esos momentos? y, de ser así ¿tenía la gravedad que el gobernador le asignaba?

Como se sabe, durante el Gobierno de Frei Montalva se dio un giro en la modalidad de acceso a la tierra, de acuerdo a lo dispuesto por la ley de reforma agraria $\mathrm{N}^{\circ} 16.640$ de 1967. De la parcelación individual inmediata aplicada en las colonias indígenas se pasó al usufructo y explotación colectiva de la tierra entregada, devenida en asentamiento (hasta su posterior parcelación definitiva). El asentamiento, entonces, suponía desarrollar una organización colectiva de gestión: tener una directiva, buscar asesoría técnica, planificar, asignar y supervigilar diversas tareas, preocuparse de la comercialización y del reparto de beneficios y utilidades. Por los testimonios con que contamos, en las dos Colonias Indígenas de la provincia no hubo mayores dificultades ni enfrentamientos entre asignatarios mapuches y no mapuches. En los asentamientos la situación fue un tanto diferente, en lo que incidió directamente el referido cambio en el acceso y gestión de la tierra entregada.

El 21 de abril de 1965 se produjo la toma simultánea de cuatro fundos en diferentes lugares de la provincia: Antiquina, Lloncao, Paicaví (en la comuna de Cañete) y Elicura (comuna de Contulmo), lo que generó un enorme impacto. La acción coordinada reveló la fuerza que había alcanzado la articulación entre diversas comunidades mapuches para presionar por el acceso a la tierra. Refrendaba, asimismo, la persistencia del apoyo brindado a las comunidades por diversos dirigentes y parlamentarios de los Partidos Comunista y Socialista. Las autoridades intentaron disuadir a los ocupantes, señalando que las 
gestiones para expropiar los fundos darían una pronta solución a su demanda.

Una vez expropiados, y comenzando el proceso de formación de los respectivos asentamientos, se manifestó con nitidez la tensión entre los ex inquilinos no mapuches y los mapuches ocupantes, muchos de los cuales habían sido trabajadores afuerinos de los mismos fundos. Alberto Huenupi, de la reducción Juanico Antinao, que fue uno de los líderes de la toma del extenso fundo Antiquina (de propiedad de la Sucesión Harismendy) y, posteriormente, presidente del asentamiento, relata:

Así que ahí nos tiramos los mapuches por la tierra también del fundo. Y los inquilinos, ellos estaban de acuerdo con la lucha por la libreta del seguro, la asignación familiar, y las ocho horas, eso perfectamente de acuerdo con uno. En lo que no estuvieron muy de acuerdo, es que querían la tierra para ellos. Así que los inquilinos estuvieron en contra de nosotros, antes de que se formara el asentamiento, no querían que nosotros entráramos, porque nosotros queríamos tener una igualdad porque habíamos mapuches que no teníamos nada más que el puro trabajo nomás, no teníamos casa, no teníamos animales, no teníamos goce, ninguna cosa. Entonces nosotros dijimos "esto no puede ser", y los diputados nos decían igual también. Así que, principalmente, los que luchaban por las tierras eran más los mapuches que los inquilinos. Porque el inquilino no tenía tierra, pero si tenía su goce, y el mapuche siempre arrinconado, arruinado en una hectárea o media hectárea de tierra, iy ahí qué más!, no tenía animales, no tenía ovejas, no tenía chanchos.

La situación fue resuelta en favor de los mapuches, que consiguieron convencer a los inquilinos de incorporarlos en pie de igualdad en los asentamientos, apoyados también por los diputados Fierro y Medel:

$\mathrm{Y}$ cuando los inquilinos estaban en contra de nosotros...vino un dirigente que se llamaba Pedro Romero, ese era un dirigente que andaba en operaciones para acá. Entonces él sabía que los inquilinos estaban en contra de los mapuches, y les dijo en una reunión: "Ustedes son inquilinos, y si hacen, dejan a un lado a los mapuches, ustedes nunca van a ganar la pelea, tienen que luchar juntos". Y así fue la cosa, porque no sacaban nada, si ellos querían tierra independiente, tener por su nombre, si no se unían con nosotros ¡qué es lo que iban a hacer!, seguían de inquilinos, y a lo mejor nosotros ganábamos la pelea en otro lado, ¿y en otro lado van a tener tierra? [...] Así que en eso, hicimos toma, todo el fundo, los mismos diputados, Fierro ${ }^{28}$ y Medel $^{29}$, nos decían "oigan compañeros, esto no va a durar más de dos años, el fundo tiene que ser expropiado" [...] Ya, se empezó a formar el asentamiento. Bueno, según, en la expropiación del fundo era para todos y, una vez que se expropió el fundo, entramos a ser asentados. Ahí entramos ciento cinco asentados, y de esos cuarenta eran inquilinos del fundo. Y en eso también ganamos la lucha nosotros a los inquilinos, porque el primer presidente del asentamiento fui yo. Entonces había jóvenes ya que trabajamos pal [19]67 al [19]73, como siete años en el asentamiento, y todos esos años lo dirigí yo. Y luego ya nosotros nos fuimos a cooperativa, el [19]68, y yo también fui el presidente de la cooperativa, si yo andaba en todas las parás [se ríe] ${ }^{30}$.

El testimonio de Huenupi revela que la fricción entre "inquilinos" y "mapuches" se proyectó en la dirección y administración tanto del asentamiento como de la posterior cooperativa (la "lucha" por la directiva). La tensión entre ambas partes, al calor de las vicisitudes de la gestión colectiva, llegó incluso al quiebre del asentamiento y la consiguiente división del terreno:

Pero ahí al final ellos, los inquilinos, conmigo se han portado siempre, igual como siempre, pero hubieron, hay runrunes ${ }^{31}$, hubieron por ejemplo que cuando se dividió, porque después que se formó el asentamiento se dividieron por la mitad, así que todos los inquilinos para allá, y los afuerinos [mapuches] para acá, solamente quedaron cuatro inquilinos con nosotros. 
Ahí se dividió el asentamiento y se dividió el terreno. Y eso fue como al año, año y medio de que formamos la cooperativa, porque nosotros, cuando ellos se dividieron, nosotros teníamos la personalidad casi lista ya, "porque era puro engaño", decían ellos. Y no pues, cuando nos vieron a nosotros organizados, y más lo que ellos no quisieron; porque nosotros hicimos, cuando también estuve en la pelea de las casas, que yo salí para el norte, hasta el Valle del Choapa, a ver cómo estaban los otros asentamientos, las otras poblaciones por ahí, así que yo vi todo eso, y bueno, no teníamos donde estar, una casitas con una bodega ya; y ahí estuvimos en la pelea por mejores casas. Así que ahí ellos formaron otra cooperativa. Por eso que a esto le pusimos nosotros, cuando nos dividimos con los inquilinos, le pusimos Lautaro-Antiquina, este ese es el nombre que tiene, si está en los documentos todo eso. Y ellos le pusieron Antiquina nomás (Alberto Huenupi).

El 12 de enero de 1967 se produjo la ocupación de otro importante fundo de la provincia, Tranaquepe, ubicado al sur del lago Lleu Lleu, de propiedad de Walter Ebensperguer, que fue tomado por un grupo de sesenta familias mapuches provenientes de cinco comunidades ribereñas del lago (El Malo, Choque, Miquihue, Ranquilhue y Ranquilhue Grande) que reclamaban derechos usurpados sobre los terrenos del fundo. La toma, liderada por el dirigente Lorenzo Carilao, de Choque, contó con el respaldo de mapuches provenientes de otros sectores (Antiquina, Paicaví, Lleu Lleu, Las Huellas) y con el respaldo directo del diputado comunista Santiago Aburto, quien alojó en la toma. Después de una semana de ocupación, se acordó comenzar las negociaciones para la expropiación. En las cerca de 2.000 hectáreas estaban radicadas 29 familias de inquilinos (casi todos no mapuches); asimismo, ocupaba una buena cantidad de trabajadores afuerinos y de medieros (entre ellos, mapuches residentes en las reducciones cercanas). Nuevamente, se expresó la tensión entre inquilinos no mapuches y ocupantes mapuches de cara a la formación del asentamiento $^{32}$. Saturnino Yevilao, uno de los vicepresidentes del asentamiento Tranaquepe, lo señala:
Sí, siempre hubo ese problema, es que hubo gente que, cuando nos fuimos a la recuperación del fundo, esos inquilinos; nosotros, si nos hubieran querido matar a todos, nos habrían muerto. La idea de ellos era eso, porque no querían que se saliera del fundo su patrón $[\ldots]$ Y hubo diferencias con los [ex]inquilinos, siempre hubo diferencias porque los inquilinos por nada querían ver a los mapuches allá o trabajar junto con ellos, no querían para nada, porque ellos, una vez que se expropió el fundo dijeron: "El patrón aquí nos entregó la tierra a nosotros". Y en eso siempre hubo diferencias porque se tomaron los trabajos mejores, como ser los camperos, los capataces eran $[\ldots]$ y bueno, a los mapuches siempre los tiraron a los trabajos más difíciles; esos los estuvimos haciendo, porque de ahí nosotros comenzamos a decir que hubo diferencias ${ }^{33}$.

La rivalidad entre ambos grupos se expresó asimismo en las disputas por el control de la organización del asentamiento, en la cual el predominio inicial de los inquilinos dio paso a un mayor equilibrio de fuerzas:

Y también cuando se forma el asentamiento se ponen dirigentes tanto del otro lado, del fundo, y gente de fuera [mapuches], así que fueron dos fuerzas ahí, quién ganaba, y ahí no alcanzamos a ganar la presidencia porque nos ganaron los inquilinos, pero se asociaban con los hermanos mapuches que trabajaban en el fundo, los winkas se ganaron a los mapuches, así que de esa manera siempre fuimos perdiendo. En cada cambio de directiva, o de cualquier cosa, siempre esa gente que fue trabajadora del fundo, ellos querían ganarse los cupos, como ser para ser el presidente, el secretario, o ser el jefe principal, ellos solamente querían ordenar, y ahí es donde siempre hubo diferencias hasta el final. Después sí ya comenzamos como que los anduvimos sobrepasando de a poco, nos fuimos recuperando, recuperando [...] porque ahí, un tiempo nosotros fuimos, sobrepasamos cuando entramos más mapuches como socios, porque ya 
éramos más gente de fuera, y en alguna medida convencimos al resto de los otros mapuches que votaban por los inquilinos, los fuimos ganando, entonces de ahí como que los fuimos sobrepasando, pero nunca llegamos a ganar lo que fue la presidencia del asentamiento, nunca lo ganamos. Llegamos a la vicepresidencia nomás, entre vicepresidente y secretario ${ }^{34}$.

Considerada por los mapuches como una relación de "humillación" y "discriminación", los avances políticos realizados por ellos les permitieron mejorar la desigual distribución de las tareas existente inicialmente:

Y por ese motivo como que siempre hubo humillación, discriminación cuando los mapuches entramos junto con los winkas [se ríe], porque ellos siempre quisieron ser ellos nomás, con repartir el trabajo se notaba, porque si a mí me echan en un trabajo difícil y otro se lleva el trabajo, pucha, regalado [...] Pero hubo un cambio, por eso le digo de que cuando nosotros ya comenzamos, la juventud [ingresaron nuevos asentados mapuches], ya hubo esa oportunidad, ya cambió la cosa, porque pudimos meter un capataz, lo que tuvo que ver con la ganadería, pudimos meter un campero que le llamaban en aquellos tiempos, tenía que ver los animales... ${ }^{35}$.

Esta brecha volvió a profundizarse, en perjuicio de los asentados mapuches del fundo, cuando se procedió a la parcelación del fundo, ya en tiempos de la dictadura militar. El proceso de calificación para acceder a las parcelas dejó afuera a la mayoría de los mapuches asentados (entre ellos, al propio Saturnino Yevilao). De las 35 parcelas que se formaron, 12 quedaron en poder de mapuches:

...Pero, cuando terminó el asentamiento, ahí se pusieron violentos todos los que no estaban de acuerdo con nosotros. No en ese tiempo fue, pucha, muy doloroso, porque aquellos que fueron parceleros, ya les asignaron su parcela, después esos nos desconocieron a nosotros mismos, porque ninguno quiso tenerle algunos animalitos ni siquiera a medias ${ }^{36}$ en sus parcelas que tenían, ni siquiera los mapuches que tocaron parcela, ninguno (Saturnino Yevilao).

La exclusión de los asentados mapuches al momento de la parcelación se produjo también en otros asentamientos de la provincia (en Lloncao y Paicaví por ejemplo, como atestigua Juan Neculqueo). Es conocido que la misma situación se verificó en muchas zonas de la vecina Región de La Araucanía (Correa, Molina y Yáñez, 2005). Ahora, en lo que a la Provincia de Arauco respecta, este proceso de exclusión -al calor de la violencia implicada en el proceso de Contrarreforma Agraria- supuso la expresión más aguda de la tensión existente entre asentados mapuches y no mapuches. Aun con esto, y de acuerdo a nuestros testimonios, el conflicto asociado a esta situación puede caracterizarse como de baja intensidad.

La brecha existente entre los mapuches y campesinos chilenos pobres a propósito del acceso a la tierra no alcanzó a desbordarse en una "lucha racial", como temía el citado gobernador Montory. En esto pudo resultar determinante el influjo ejercido por los partidos de izquierda en el movimiento mapuche provincial. El discurso de clase y campesino, con el que dichos partidos conceptualizaban y pretendían conducir el proceso de acceso a la tierra, habría contribuido a atenuar la manifestación plena de una confrontación basada en diferentes identidades étnicas en el seno de los sectores populares. La tensión existente entre ambos polos se evidenció y se resolvió en el acotado nivel de la gestión y administración de los asentamientos (los perjuicios que sufrieron aquí los mapuches son significados en la dimensión de la "injusticia").

A la vez, el influjo partidario y sindical le permitió a las comunidades de la provincia limitar la plena expresión de un discurso étnico de reivindicación de derechos territoriales en tanto pueblo (ya no como campesinos), el que pudiera haber llevado a una confrontación más abierta con los asentados no mapuches.

\section{El asentamiento Paillaco y la presencia del MIR}

Muy avanzado el proceso de reforma agraria se constituyeron asentamientos integrados solamente por mapuches. Fueron situaciones 
muy excepcionales. Tal fue el caso del recordado asentamiento Paillaco, establecido en el ex fundo del mismo nombre ubicado en las riberas del lago Lleu. El fundo fue expropiado a una integrante de la familia Ebernsperguer ${ }^{37}$. En Paillaco fueron asentadas cerca de cuarenta familias mapuches procedentes de las cercanas reducciones de Lolcura, Miquihue, Ranquilhue y Ranquilhue Chico, que no habían sido integradas a ninguno de los asentamientos constituidos hasta entonces. La vía que utilizaron estas familias para acceder a esta solución fue la toma del terreno. Pero la toma, ocurrida en marzo de 1971, ya bajo el Gobierno de la Unidad Popular, no afectó al fundo Paillaco, sino a la reserva que Walter Ebensperguer se había dejado en Tranaquepe al expropiarse ese predio $^{38}$. Luego de un mes en toma, las autoridades ofrecieron a los ocupantes una solución que contemplaba asentarse en otros fundos en poder de la CORA: el fundo Choque (expropiado a la familia Harismendy) o el mencionado Paillaco. Los ocupantes optaron por este último.

La formación del asentamiento Paillaco se diferencia de los episodios ya referidos por la irrupción de un nuevo actor en la Provincia: el Movimiento de Izquierda Revolucionario (MIR). Juan Pilquimán, uno de los asentados de Paillaco, relata:

Juan:...Ahí [en el asentamiento] habíamos algo de 30 o 40 a lo menos. No recuerdo muy bien tampoco. Habíamos hartos, llegamos puros mapuches [...] Venían del MIR, eran gente del MIR. Pero nos ayudaron harto esa gente, esa gente fueron educadas y esos [fueron los] que nos metieron en Tranaquepe, con ellos. No fuimos solos. Así, llegaron varios como dándonos instrucciones [...] $\mathrm{Y}$ esa gente, ¿cuánto que eran la gente esa?, ¡universitarios!, andaban como once, no eran mapuches. Y esos, nosotros los cuidábamos también, ellos nos ayudaban [...] Entonces ahí llegó la autoridad, llegaron los dueños del terreno y ahí venían a conversar que habían dos fundos desocupados "Y ustedes ahora -nos dijeron- pueden elegir cuál fundo, ahí está Paillaco, ahí está Choque". Entonces, nosotros nos quedamos en Paillaco.
Pregunta: $¿ Y$ en Paillaco, seguían trabajando con estos estudiantes, después que se cambiaron?

Juan: Sí, siguieron con nosotros, como que dándonos todos los datos, cómo hacerlo, cómo reclamar, cómo hacer los papeleos, todo eso para que quedáramos en limpio. No, allá, cualquiera de ellos que llegaran, nosotros los apoyábamos, le dábamos alojamiento, porque esos fueron los que nos hicieron ser valientes y tomar el terreno... ${ }^{39}$.

La entrada de estos comuneros en la reserva Tranaquepe -de la mano de la colaboración del MIR- generó fricciones con miembros del circundante asentamiento homónimo, mayormente vinculados (al menos los asentados mapuches) al Partido Comunista:

...Porque, los comunistas también no se sintieron bien cuando nosotros entramos con los del MIR. Sí, también nos atropellaron un poco a nosotros ellos, no se sintieron bien [...] pero algunos, igual nos ayudaron en alguna la cosa. Algunos, pero no todos, algunos dijeron "están bien", y otros que dijeron que ellos iban a hacer la parcela después (Juan Pilquimán).

Como se puede constatar en el testimonio de Juan Pilquimán, la entrada del MIR en este proceso significó la presencia de actores políticos de izquierda con un nuevo perfil: jóvenes, universitarios, no mapuches. Características que los alejaban del rostro sindical, minero y/o parlamentario hasta entonces predominante entre los activistas que habían apoyado a las comunidades mapuches en su lucha por la ampliación de sus tierras. Hasta donde sabemos, la presencia del MIR en Arauco, fue bastante acotada ${ }^{40}$. Así, "el asentamiento del MIR"41, como todavía lo denominan los habitantes de Lleu, ha permanecido como el recuerdo más vívido de la actividad de dicha organización en la zona durante los años de aplicación de la reforma agraria ${ }^{42}$.

\section{La represión post golpe de Estado}

La persecución política desatada tras el golpe de estado de 1973 se dejó sentir incesantemente 
sobre aquellos dirigentes mapuches de mayor reconocimiento a nivel provincial de ese entonces. Juan Neculqueo, Jovelino Liencura y Antonio Antinao (ex gobernador de Cañete), entre otros, fueron detenidos y pasaron largos meses apresados en campos de detención como el de la Isla Quiriquina e, incluso, en el de Chacabuco, en el norte del país. La represión alcanzó también a muchos dirigentes de base y miembros de asentamientos ${ }^{43}$.

Juan Pilquimán y su esposa, Ana Pilquimán, relatan cómo la violencia policial golpeó su hogar en el asentamiento Paillaco, durante un allanamiento producido pocos días después de golpe, cuando sus hijos pequeños se encontraban solos:

Ana: ....El golpe de Estado, cuando estaban los chiquillos, cuando los pillaron solos, los dieron vuelta cuanto pudieron y humillaron a los niños, ¡qué no hicieron esa vez los militares! [Estaban] los niños solos, buscando armas andaban.

Pregunta: ¿Cuándo fue eso?

Juan: Cuando fue el golpe

Ana: Unos días después. Andaban buscando armas, iqué armas íbamos a tener nosotros! No teníamos armas [...] pillaron a los chiquillos solos, los chiquillos llorando cuando yo llegué. Andaba dejando mi trabajo yo...él [Juan] andaba en el trabajo, llegué y los niños estaban llorando que habían llegado los carabineros, que habían echado todo para afuera y les sacudieron, dieron vuelta la cama, todo dieron vuelta buscando armas, y eso fue una grande humillación.

Juan: A lo mejor, ellos tenían sospechas de esos estudiantes [del MIR] ${ }^{44}$, que nos han dejado algo, armados, pero no...

Ana: ¡Qué armas!

Esta misma área ribereña del lago Lleu Lleu es, además, un buen ejemplo de otro rasgo que caracterizó a la represión desatada sobre los mapuches una vez producido el golpe de estado, rasgo que ha sido destacado en otros lugares (Morales, 1999: 105). Nos referimos a la activa colaboración que algunos terratenientes prestaron al accionar de las fuerzas represivas. Algunos de estos agricultores habían visto expropiados sus fundos (o parte de ellos) durante el proceso de reforma agraria. Tal el caso de Walter Ebensperguer, cuya casa en el ex fundo Tranaquepe habría servido como centro de detención. Juan Carilao, señala:

Juan:...Porque un primo mío, creo que lo trajeron ahí [casa de Ebensperguer], ahí lo vinieron a, digamos, cómo llaman a, a torturar, a interrogar, interrogar era torturar.

Pregunta: ¿Y estaban ahí en la casa?

Juan: Claro, estaban ahí en la casa, en la misma casa dice que lo trajeron a él con otro, con dos, tres más creo que llegaron hasta ahí decía [...] después del golpe, porque después del golpe ellos empezaron a buscar campesinos, a buscar gente, dirigente.

Pregunta: Después más a lo largo de los $70, \operatorname{los} 80$, ¿seguía eso o no?

Juan: Eso ya seguía después, digamos, disimuladamente, porque en el caso de nosotros aquí, mi papá era vigilado casi todas las semanas. Los $\operatorname{pacos}^{45}$ de Tirúa venían nomás, se hacían amigos de él, "cómo está Ud.", pero nada más que venían a ver qué es lo que hacía.

Algunos pequeños propietarios no mapuches participaron también en la represión y persecución de mapuches (como también de campesinos no mapuches) que adherían, real o supuestamente, a los partidos de izquierda. En contacto más cotidiano con quienes integraban las "reducciones" o asentamientos cercanos, las casas de algunos de estos pequeños agricultores habrían servido de centros de detención donde se torturó a sus vecinos. Juan Carilao señala que él, junto a su padre, Lorenzo Carilao, y varios más, fueron detenidos y torturados en la propiedad de Santos Jorquera, en Puerto Choque (lago Lleu Lleu), actualmente convertida en camping. Algunos de los detenidos en este lugar fueron luego trasladados a los campos de detención de Collao (en Concepción) y de Isla Quiriquina:

Juan: ...Eso fue un centro de tortura, porque eso, que a nosotros nos llevaron ahí, a mi papá, a un hermano y así a varios más. Si andábamos como 15 personas en un vehículo adonde don Santos. 
Pregunta: ¿Y los detuvieron a todos juntos?

Juan: A todos juntos y después nos echaron, él mismo prestó un calabozo, el señor Jorquera. Y ahí estuvimos todo el día, y después nos iban largando uno por uno, de acuerdo a no sé qué, y los demás se los llevaron. Se llevaron a mi papá, a un cuñado mío que andaba ahí también y como 5, 6 se llevaron directamente: "A estos los vamos a llevar para Talcahuano", "los vamos a llevar a la Quiriquina"; de eso hablaban los pacos "ya, los vamos a llevar a la Quiriquina, allá van a ir a dar su viaje, si vuelven, vuelven, si no se van a quedar por allá".

[Así] mi papá fue, ahí llevaron a este, Polo [Leopoldo] Milllahual, un tal Alberto Carbullanca que todavía vive por ahí, y otro cabro, Millabur, Juan Baustista Millabur, era un cabro que militaba en el Partido [Comunista], no era de esos [dirigentes]. Y unos vecinos del otro lado, del fundo de Choque, quedan todavía ahí, un tal Elicer Flores

Pregunta: ¿Cuánta gente hubo detenida ahí, mapuche básicamente?

Juan: Algo de 12, 13, y dos huincas, el cuñado [mío] que era Jarpa y Flores.

Saturnino Yevilao, relata las torturas a las que fue sometido su abuelo, Lorenzo Carilao, así como los demás detenidos, en la propiedad de Jorquera:

Saturnino: Y como también era uno de los autores de las tomas de los terrenos, entonces, los enemigos tenían muy en claro quién era Lorenzo Carilao, por eso lo persiguieron y pasó muy malos ratos en aquellos tiempos. Y, por el otro lado también, es que lo acusaban, ahí mismo había un señor Jorquera, Santos Jorquera, era del mismo Choque, y tenía, tiene tierras dentro de la comunidad. Y ese se prestó en el tiempo de la dictadura para, para echar al agua al que no le parecía. Era uno de los que estuvo al servicio de la dictadura.

Pregunta: ¿Y lo detuvieron al poco tiempo del golpe a su abuelo?
Saturnino: Sí, como a los 15 días. No recuerdo muy bien sí la fecha, pero el mismo septiembre. Lo llevaron al estadio nacional [regional] de Concepción, después de que los ahogaron en el lago Lleu. Ahí los sumían, los hacían pasar por debajo de una lancha. Dice que los amarraban de los pies, de los brazos y no sé de qué manera los tiraban con un cordel y los hacían pasar por debajo de una lancha y los sacaban bien ahogados y de ahí, los sacaban otra vez y haciéndole preguntas para que dijera cosas, pero él dice que no dijo nada, porque no sabía tantas cosas.

En la zona ribereña del Lleu, el accionar de estos pequeños agricultores como Jorquera aun en la actualidad genera conflictos. Gladys Huenumán, ex militante de las juventudes comunistas y sobrina política de Juan Carilao, recalca este aspecto:

Gladys: Mi mamá fue casada con el hijo de Lorenzo Carilao, que fue Manuel Carilao, también fue torturado acá en el lago, en Puerto Choque, donde don Santos Jorquera, toda la familia, fue Juan Carilao, Manuel Carilao, Segundo Neguey Carilao, nieto del abuelo Carilao, fueron todos llevados a, torturarlos en el lago. Y ahí había un colegio, donde los estudiantes, los niños fueron todos testigos cómo llegaron las personas mapuches, no mapuches.

Pregunta: ¿Qué otra gente de esos lados también sufrió en ese momento?

Gladys: También José Pilquimán, y Domingo Millahual que muere, falleció; Carinao también, no recuerdo el nombre y Osvaldo Millahual que también en paz descanse y Juan Pilquimán, también.

Pregunta: Todos de estas comunidades ribereñas.

Gladys: Sí.

Pregunta: ¿Cuál era la característica de ellos, eran todos dirigentes, militantes, o no necesariamente?

Gladys: Eran militantes, los Pilquimanes, supuestamente ellos eran del MIR, pero los otros eran todos del Partido Comunista, y por ser comunistas y por 
defender nuestros derechos como mapuches, igual esa fue la persecución que hicieron en dictadura y yo creo que todavía no se ha terminado.

Gladys:....Después nosotros logramos entre el Partido Comunista, la Izquierda Cristiana, el MIR parece que también, fuimos capaz de hacerle una funa a Santos Jorquera. Participó Juan Carilao de acá, yo, Segundo Neguey, y así, otros dirigentes de otras comunidades. Y ahí ya el caballero no debería haber estado ahí $[\ldots .$.$] nosotros fuimos a la casa a ha-$ cerle la funa donde fueron torturados los Carilao, los Pilquimanes. Estuvimos ahí y donde nosotros le decíamos que se fuera de ahí, porque nosotros no [lo] queremos tener permanentemente; todavía él está resguardado, los hijos están resguardados por la policía [...] cuando nosotros, esa vez, fuimos a hacer esa funa, todavía existía esa bodega donde guardaban los botes [desde los que sumergían a los prisioneros en el lago]... ${ }^{46}$.

Es obvio que no todos los pequeños agricultores no mapuches de la zona participaron o colaboraron en acciones represivas y, en la generalidad, las relaciones entre los mapuches del sector y los pequeños propietarios no mapuches con los que convivían pueden caracterizarse por una relativa normalidad. Así también, existen antecedentes acerca de unos pocos mapuches implicados en la delación ante las autoridades de la época de integrantes, reales o supuestos, de grupos opuestos al régimen militar.

En el testimonio de Gladys Huenumán se puede apreciar también la persistencia, bajo la dictadura, de la articulación entre grupos de mapuches con los partidos o agrupaciones de izquierda tradicional en la denuncia pública de las acciones de violencia de las que habían sido o eran víctimas. La mayoría de los mapuches más activos seguían militando en dichos partidos, principalmente a través de los capítulos provinciales de organizaciones mapuches como Ad Mapu, desde inicios de los años ochenta; o los Centros Culturales Mapuches, en años previos. Dicha vinculación se manifestaba no solo en actividades de denuncia, sino también en una serie de acciones reivindicativas, entre las que podemos destacar la realización de juegos de palín o nguillatunes convocados coincidentemente con la realización de jornadas de protesta, de alcance nacional, contra la dictadura militar. El más conocido de estos episodios ocurrió en la comunidad de Miquihue (Lleu Lleu) durante el paro nacional del 27 de marzo de 1984. Un juego de palín, convocado sin solicitar el permiso ante las autoridades locales, como se estilaba entonces, derivó en enfrentamientos con carabineros que dejaron a algunos mapuches heridos a bala. También siguieron ocurriendo tomas de terrenos, particularmente durante el segundo lustro del decenio de los ochenta. Aquí destaca, nuevamente, la reserva de terreno que los Ebensperguer se dejaron luego de expropiado el fundo Tranquepe, reserva conocida con el nombre de "Los Canelos", la que fue ocupada por mapuches de las comunidades de Choque y Miquihue principalmente, en varias ocasiones desde el año 1986. La última de estas tomas ocurrió el año 1991, ya restablecida la democracia, y con ella los mapuches de la Provincia de Arauco volvieron a reiterar la demanda de restitución de sus tierras usurpadas.

\section{Conclusiones}

Tal como el resto de la sociedad mapuche, las comunidades de la costa de Arauco fueron incorporadas obligadamente al Estado nacional chileno a fines del siglo XIX. La expresión más masiva de esta violencia fue el despojo territorial a través del proceso de radicación, que puso incluso en peligro sus condiciones de reproducción. A partir de ahí, la restitución de las tierras usurpadas se constituyó en la principal exigencia de dichas comunidades frente al Estado.

La historia de la expoliación territorial y la respuesta mapuche en Arauco revela rasgos y procesos específicos respecto de otros segmentos de la sociedad mapuche. Particularmente, se puede destacar la decisiva y temprana incidencia de la cultura sindical minera (carbonífera) en la organización de la demanda por la restitución de tierras de los mapuches de la Provincia. La vinculación entre sindicatos carboníferos y comunidades mapuches atravesó gran parte del siglo XX. El caso más emblemático es el de la toma de la Isla Pangal (Los Álamos) en 1962, la que se adelantó en casi una década a las "corridas de cerco" y tomas de fundos que se produjeron masivamente en toda la 
zona mapuche hacia fines de los 60 s y principios de los 70s. Los esfuerzos por impulsar y propagar la sindicalización campesina (a partir de la ley de sindicalización campesina, de 1967) encontraron en Arauco un terreno ya maduro para fructificar, particularmente en algunas zonas de la Provincia, como las comunidades mapuches de Huentelolén, al sur de Cañete. Hay aquí una continuidad histórica que no se presenta en el resto del mundo mapuche, donde el nexo entre sindicalización y lucha por recuperación territorial se despliega a partir de la agudización de la profundización del proceso de reforma agraria entre fines de los $60 \mathrm{y}$ el año 1973.

El impacto de la reforma agraria entre los mapuches de Arauco fue muy significativo, duplicando la cantidad de tierra entregada en comparación al proceso de radicación de principios del siglo XX. A la vez, al fragor de la constitución de los asentamientos y su posterior parcelación, no dejaron de expresarse agudas tensiones entre mapuches y campesinos no mapuches. En algunos casos, dichas tensiones se manifestaron posteriormente en acciones de delación hacia dirigentes mapuches en el contexto de la represión desatada luego del golpe de Estado de septiembre de 1973.

Junto con la especificidad histórica de la provincia de Arauco dentro del contexto general de las luchas mapuches del siglo XX, la indagación realizada evidencia el aporte de la historia oral en los estudios sobre el tema, permitiendo no solo reconstruir hechos específicos, sino sobre todo conocer la forma en que las propias comunidades vivieron los procesos históricos en los que fueron parte activa ${ }^{47}$.

\section{Agradecimientos}

Agradecemos al Dr. Pedro Araya, de la Universidad Austral de Chile, su generosa colaboración.

\section{Referencias Citadas}

Bengoa, José

1987 Historia del pueblo mapuche, siglos XIX y XX. Ediciones Sur, Santiago.

Cárcamo, Ovidio

2016 "Movimiento Campesino Revolucionario y Consejos Comunales Campesinos de base. Una experiencia de poder popular en Chile", en: Desacatos 52, pp. 94-111.

Chamorro, Claudia

2008 La familia Melita: persistencia política y permanencia territorial mapuche en la zona de Arauco, 1726-2008. Tesis para optar al título de Antropóloga Social, Universidad de Chile, Santiago.

Correa, Martín; Molina, Raúl y Yáñez, Nancy

2005. La reforma agraria y las tierras mapuches. LOM Ediciones, Santiago.

Durán, Teresa; Bacic, Roberta y Pérez-Sales, Pau

1998 Muerte y desaparición forzada en La Araucanía: una aproximación étnica. Ediciones Universidad Católica de Temuco, Temuco.

Foerster, Rolf y Montecino, Sonia

1988 Organizaciones, líderes y contiendas mapuches (1900-1973). Ediciones CEM, Santiago.

Correa, Martín; Molina, Raúl y Yáñez, Nancy

2005 La reforma agraria y las tierras mapuches. LOM Ediciones, Santiago.

Foerster, Rolf

2008 "Los procesos de constitución de la propiedad en la frontera norte de la Araucanía: sus efectos esperados y no esperados en el imaginario y en la estructura de poder", en: Cuadernos de Historia 28, pp. 7-35.
2018 ¿Pactos de sumisión o actos de rebelión? Una aproximación histórica y antropológica a los mapuches de la costa de Arauco, Chile, Pehuén Editores, Santiago. Presentada originalmente como Tesis Doctoral en Historia, Universidad de Leiden, Holanda, en 2004.

Godoy, Arturo

2018 "Historia del Pangal, los mapuches, la rebelión en la década del 60; Los Álamos", en: Mapuexpress (http:// www.mapuexpress.org/?p=386). Visitado el 25 de febrero de 2018.

González, Héctor

1986. "Propiedad comunitaria o individual. Las leyes indígenas y el pueblo mapuche", en: Nütram 3, pp. 7-13.

Guevara, Tomás y Mankilef, Manuel

[1913] 2002 Kiñemufütrokiñcheñi piel. Historias de familias. Siglo XIX. CEDM-Liwen- CoLibris, Santiago.

Hoffman, Alice

1987 "Reliability and validity in oral history". En Oral History, editado por David Dunaway y Willa Baum (Eds.) American Association for State and Local History (AASHL), Nashville, $2^{\text {a }}$ edición, pp. 67-73.

Mallon, Florencia

2004 La sangre del copihue. La comunidad Mapuche de Nicolás Ailío y el Estado chileno, 1906-2001. LOM Ediciones, Santiago.

Molina, Raúl

S/f. Las tierras mapuches de Arauco. Manuscrito.

1989 Mawidam. Historia de la comunidad mapuche-huilliche de Monte Verde. Canelo de Nos, Santiago. 
Molina, Raúl y Correa, Martín

1996 Territorio y comunidades pehuenches del Alto BíoBío. CONADI, Santiago.

1998 Las tierras huilliches de San Juan de la Costa. CONADI, Santiago.

Morales, Roberto

1991/1992 "Violaciones al derecho a la vida de los mapuches", en: Nütram Año VII, Nº 24, pp. 24-38.

1999 "Cultura mapuche y represión en dictadura", en: Revista Austral de Ciencias Sociales 3, pp. 81-108.

Portelli, Alessandro

2002 "Las fronteras de la memoria. La masacre de las Fosas Ardeatinas. Historia, mito, rituales y símbolos", en: Sociohistórica 11-12, pp. 163-176.

$2004 \mathrm{La}$ orden ya fue ejecutada. Roma, las Fosas Ardeatinas, la memoria. Fondo de Cultura Económica, Buenos Aires-México.
Redondo, Jesús

2016 "El conflicto mapuche en Chile durante el proceso de reforma agraria: el ejemplo de la provincia de Cautín entre 1960 y 1973", en: Historia Agraria 70, pp. 131-160.

Samaniego, Augusto y Ruiz, Carlos

2007 Mentalidades y políticas wingka: pueblo mapuche, entre golpe y golpe (de Ibañez a Pinochet). Consejo Superior de Investigaciones Científicas, Madrid.

Thompson, Paul

1986 The voice of the past. Oral history. Oxford University Press, 3a reimpresión, Oxford.

Todorov, Tzvetan

1995 Los abusos de la memoria. Barcelona, Paidós, 2015.

2013 Los usos de la memoria. Santiago: Museo de la Memoria y los Derechos Humanos.

\section{Notas}

1 Lorenzo Neculqueo, Juan Viluñir, Santos Huenullán, Juan Neculqueo, Juan Carilao, Jovelino Liencura, Alfredo Aniñir, Silvia Naín, Alberto Huenupi, Saturnino Yevilao, Juan Pilquimán, Ana Pilquimán y Gladys Huenumán.

2 En este sentido, son destacables los estudios de Bengoa (1987); Correa, Molina y Yáñez (2005); Mallon (2004); Molina (1989); Molina y Correa (1996 y 1998) y el precursor trabajo de Tomás Guevara y Manuel Manquilef ([1913] 2002).

3 Entrevista a Lorenzo Neculqueo, realizada en Chapó (sector Tranaquepe, comuna de Tirúa), 24 de noviembre de 2015.

4 Expresión coloquial usada en Chile, sinónimo de "persiguieron".

5 Entrevista a Juan Viluñir Garrido, en Puchacay (Valle de Cayucupil), comuna de Cañete, 1 de febrero de 2016.

6 De la comunidad Francisco Epullán, sector de Huape, comuna de Cañete.

7 De la comunidad Francisco Epullán, sector de Huape, comuna de Cañete.

8 O sea, haciendo juicio contra los expoliadores.

9 Entrevista a Santos Huenullán, realizada en Huape, comuna de Cañete, 25 de noviembre de 2015.

10 Entrevista a Juan Neculqueo, realizada en Huentelolén (comuna de Cañete), 19 de diciembre de 2015.

11 Entrevista a Juan Carilao, realizada en Choque Alto, 8 de febrero de 2016.

12 De acuerdo a Foerster y Montecino (1988: 170), después 1945 -cuando Venancio Coñuepán salió elegido diputado- el FUA mostró ya señales claras de "reducción programática y organizacional".

13 Para una reconstrucción del debate de la izquierda chilena sobre el problema mapuche entre el Frente Popular y el gobierno de Ibáñez, véase: Ruiz y Samaniego (2007, Cap. IV: 207-264).

14 Entrevista a Jovelino Liencura, realizada en Lebu, 23 de julio de 2007.

15 Entrevista a Jovelino Liencura, realizada en Lebu, 23 de julio de 2007.

16 Entrevista a Jovelino Liencura, realizada en Lebu, 23 de julio de 2007.

17 Obviamente, dentro del contexto general campesinista que guiaba a todo el proceso de reforma agraria, resumido en el concepto emblema "La tierra para el que la trabaja". Como bien destacan Correa, Molina y Yañez (2005) la demanda mapuche por "restitución de tierras" desbordaba, "colocaba en interdicción" dicha política, forzando al Estado a abrirse a buscar una solución a las comunidades y familias mapuches que presionaban, vía tomas, por acceder a las tierras reformadas sin haber sido, en su inmensa mayoría, trabajadores de los fundos expropiados.

18 Entrevista a Alfredo Aniñir, realizada en Los Álamos, 29 de diciembre de 2015.

19 Diputado del Partido Comunista entre 1961-1965 por la Decimoctava Agrupación Departamental "Lebu, Arauco y Cañete" (Biblioteca del Congreso Nacional de Chile, Historia Política, Reseñas Biográficas, www. ben.cl).

20 Senador por la Séptima Agrupación Provincial "Ñuble, Concepción y Arauco" entre 1961 y 1969. Desde 1958 y hasta 1990, fue además Secretario General del Partido Comunista (Biblioteca del Congreso Nacional de Chile, Historia Política, Reseñas Biográficas, www.bcn.cl).

21 Al respecto, véase: Foerster (2018: 286-296).

22 "Los mapuche se consolidaron en la Isla de Pangal, Loncomahuida y Pillán, y luego en otros lugares, consiguiendo posteriormente, de acuerdo a la propia Ley 15.020, de Alessandri, llamada "del Macetero", la expropiación de los fundos de Paicaví, Lo Prado y Hueñalihuén y llegando así a recuperar 20.000 hectáreas" (Samaniego y Ruiz 2007: 270).

23 Entrevista a Silvia Naín, realizada en Cañete, 22 de diciembre de 2015.

24 Según Godoy (2018), la toma recibió el apoyo de los diputados Fermín Fierro (PS) y Santos Leoncio Medel (PC), además de un conocido dirigente de la zona, Pascual Melita Pereira, militante comunista y regidor de Los Alamos entre 1960 y 1971. Sobre este último, véase: Chamorro (2008: 131-138).

25 Junto al fundo Pangue, se expropiaron los fundos Ranquilco y Sara de Lebu, también pertenecientes a la familia Eyheramendy.

26 Fue parlamentario por el Partido Socialista (1957-1961) y luego por el Partido Comunista (1961-1973) por tres períodos sucesivos. 

de Tierras y Colonización, año 1963, serie Oficios, Vol. V, oficio 4133, cit. por Foerster (2018: 288-289).

28 Fermín Fierro Lungo, diputado socialista por dos períodos (1961-1965 y 1965-1969) por la Decimoctava Agrupación Departamental "Lebu, Arauco y Cañete" (Biblioteca del Congreso Nacional, Historia Política, Reseñas Biográficas, www.bcn.cl).

29 Se refiere al Diputado comunista, Santos Leoncio Medel (véase la nota 23 ).

30 Entrevista a Alberto Huenupi, realizada en Antiquina, 2 de diciembre de 2007.

31 Rumores, intrigas.

32 El asentamiento, constituido en 1969, contó inicialmente con 65 asentados, de los cuales 25 eran mapuches, la mayoría ex trabajadores afuerinos del fundo (Entrevista a Lorenzo Neculqueo, Sector Tranaquepe, Comuna de Tirúa, 24 de noviembre de 2015).

33 Entrevista a Saturnino Yevilao, realizada en Huape, 22 de noviembre de 2015.

34 Entrevista a Saturnino Yevilao, realizada en Huape, 22 de noviembre de 2015.

35 Entrevista a Saturnino Yevilao, realizada en Huape, 22 de noviembre de 2015.

36 Trato entre dos campesinos que se asocian. En el caso que cita el entrevistado, un socio aporta el terreno para que su asociado (que carece de tierra) pueda dejar sus animales pastando en él. Luego, al momento de las pariciones, las crías se dividen en partes iguales.

37 Como se recordará, es la misma familia a la que ya se le había expropiado el cercano predio de Tranaquepe.

38 El Sur, de Concepción, informaba: "Mapuches Requisaron Armas en Arauco

Cuatro rifles, una carabina y una escopeta fueron "requisados" por 59 mapuches desde una dependencia de las casas patronales del fundo Tranaquepe, de la provincia de Arauco, sin que se haya producido enfrentamiento.

El intendente de Arauco, Domingo Aguirre, dijo ayer en Concepción que esos indígenas se habían tomado el fundo de 1.200 hectáreas, "reclamando la propiedad de las tierras que antiguamente pertenecieron a sus antepasados". Desgraciadamente el predio fue expropiado hace años por la CORA y aún no se ha hecho la subdivisión entre los miembros de la sucesión Ebensperguer.

"Según las informaciones que poseo, de acuerdo con la repartición que debe hacerse de 120 hectáreas regadas, cada uno de los beneficiarios tocaría alrededor de 40, que en ningún caso serán entregadas a otros ocupantes que no sean sus dueños", dijo el intendente de Arauco.

Aguirre, junto con el gobernador de Cañete, concurrió ayer en la mañana al fundo Tranaquepe. Allí se impuso de que los mapuches habían requisado esas armas "previniendo que fueran usadas en su contra. Ellos ofrecieron entregármelas, pero yo no me he hecho cargo de las armas, pues primero tengo que comprobar si efectivamente están registradas a nombre del administrador del fundo, Walter Ebensperger, como él manifestó. Para esto está citado para mañana (hoy) a la Gobernación de Cañete......Hemos adoptado las medidas pertinentes para evitar enfrentamientos, y debo decir que fueron los mapuches los que me solicitaron protección policial para evitar choques fatales. Hay carabineros con radio para llamar de inmediato a la Gobernación de Cañete y enviar refuerzos policiales".

Los mapuches levantaron las barricadas tras las que se habían protegido luego de la toma del fundo Tranaquepe, y enviaron a sus dirigentes a la capital. En Santiago se entrevistarán con funcionarios de la CORA, a quienes solicitarán que se les destine otro predio para que puedan tener posibilidades de trabajar en la agricultura.

"Creo que el viernes todo este problema estará solucionado, sin que la sangre haya llegado al río. Los mapuches hablaron conmigo y me demostraron su conformidad por el hecho de que no se les haya entregado el predio que ocuparon y esperan tranquilamente la solución que se les dará desde los organismos respectivos", informó el intendente Aguirre".

(El Sur, Concepción, 18 de marzo de 1971, pág. 14).

39 Entrevista a Juan Pilquimán, realizada en Anique, Cañete, 6 de febrero de 2016.

40 Lo que marca un contraste con lo ocurrido, durante este mismo período, en experiencias paralelas de recuperación territorial en la vecina región de La Araucanía, donde la presencia del MIR y de su filial campesina, el Movimiento Campesino Revolucionario (MCR), fue especialmente activa y significativa en reducciones y comunidades mapuches de la Provincia de Cautín (Redondo 2016 y Cárcamo 2016).

41 Los terrenos que conformaron dicho asentamiento hoy están mayoritariamente en poder de la empresa Forestal Mininco.

42 Junto al establecimiento del asentamiento Paillaco, tenemos antecedentes de actividades de miembros del MIR, en 1973, apoyando tomas de terreno de una comunidad mapuche en Locobe, al norte de la provincia, cerca de la ciudad de Arauco ("Instigados por el MIR. Movilización indígena tras restitución de tierras de antepasados", El Sur, Concepción, 27 de mayo de 1973, pág. 13).

43 Para una perspectiva general sobre la represión hacia el pueblo mapuche, véase: Correa, Molina y Yañez (2005: 276-291); Durán (1998); Mallon (2004: 133-177) y Morales (1989 y 1991/1992).

44 La represión política alcanzó, por supuesto, a estos activistas del MIR. Al respecto, Juan Pilquimán señala, escuetamente: "Y después, cuando hubo el golpe, tomaron como a dos y los echaron al lago [Lleu Lleu], decían".

45 Policía uniformada.

46 Entrevista a Gladys Huenumán, realizada en la comunidad Venancio Neguey (Lleu Lleu), 4 de febrero de 2016.

47 "Si lo que queremos es sumergirnos en la vivencia de los actores, el relato del testigo es irremplazable" (Todorov 2013: 27). Al respecto, véase: Thompson (1986). 